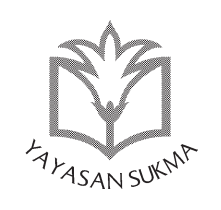

SUKMA: JURNAL PENDIDIKAN

ISSN: 2548-5105 (p), 2597-9590 (e)

Volume 4 Issue 1, Jan-Jun 2020, pp. 1-23

https://doi.org/10.32533/04101.2020

www.jurnalsukma.org

\title{
ENIGMA PLURALISME BANGSA Memposisikan Peran Perguruan Tinggi Islam
}

\section{Ratno Lukito}

Universitas Islam Negeri Sunan Kalijaga Yogyakarta, Indonesia email: ratnolukito@yahoo.com

\section{Abstract}

Pluralisme merupakan kosa kata baru bagi orang Indonesia, meskipun pengalaman dalam hal pluralisme ini sudah lama ada. Kosa kata ini semakin menjadi asing di tengah masyarakat, terlebih sejak keluarnya fatwa MUI tahun 2005 yang menolak ide pluralisme keagamaan. Indonesia dengan ribuan pulaunya tentu saja menganut pluralisme karena perbedaan kultur dan nilai budaya yang ada. Pluralistic state adalah sebuah kenyataan. Bagaimana Perguruan Tinggi Keagamaan Islam (PTKI) di Indonesia menghadapi problem pluralisme ini? Bagaimana pula posisi pergu- 
ruan tinggi ini di tengah mayoritas umat Islam sebagai penduduk dominan di negeri ini? Dengan orientasi baru sebagai pluralistic university, PTKI mampu merevitalisasi perannya dalam negara Indonesia modern. Hubungan antar unsur civitas academica di dalamnya tidak lagi merefleksikan bentuk relasi atas-bawah melainkan lebih sebagai hubungan sejajar dari berbagai bentuk asosiasi yang beragam. Hanya dengan perspektif pluralistis inilah, kajian-kajian yang dilakukan di dalamnya akan mampu merefleksikan Islam sebagai raḥmah lil-'àlamīn.

Keywords: pluralism, pluralistic state, PTKI, formal curriculum, hidden curriculum.

\section{A. Pendahuluan}

Pluralisme barangkali merupakan istilah yang tidak begitu disukai di Indonesia. Utamanya semenjak keluarnya fatwa MUI pada 2005 yang menolak pluralisme, term ini seolah menjadi istilah haram (an abhorrent phrase) bagi sebagian kalangan masyarakat karena bisa menggambarkan kecenderungan penggunanya kepada pikiran-pikiran yang cenderung membelokkan nilai-nilai Islam dari kemurniannya. Ketika sebuah penerbit di Jakarta hendak menerbitkan terjemahan disertasi penulis tentang pluralisme hukum pada 2008, mereka cukup kerepotan menentukan apakah buku itu akan diterbitkan dengan judul pluralisme hukum atau dengan judul lain. Mereka khawatir penggunaan term "pluralisme" tersebut akan berdampak buruk bagi kelangsungan pemasaran buku itu. Walhasil buku itu pun muncul dengan judul lain tanpa secara langsung menggambarkan tema pluralisme hukum yang menjadi misi dari karya aslinya. Pada tahun yang sama, sebuah lembaga swadaya masyarakat (LSM) di Jakarta akhirnya harus berhadapan secara frontal dengan kelompok masyarakat Islam tertentu lantaran nama lembaga tersebut yang secara eksplisit menggunakan term "pluralisme", 
karena konsen mereka yang memang difokuskan pada pengembangan pemikiran masyarakat Islam yang pluralis.

Contoh di atas hanya sekadar gambaran, betapa kita saat ini dihadapkan pada suatu kebimbangan: di satu sisi kita tidak bisa menolak kenyataan pluralisme tersebut, tapi di sisi lain kita berhadapan dengan sikap dan tingkah laku yang didorongkan kepada kita untuk tidak menerima fakta pluralisme itu sendiri. Di sinilah kita menghadapi apa yang bisa disebut dengan "keterputusan epistemologis" (epistemological break) dalam menghadapi fenomena ini. Pertanyaannya, bagaimanakah kita harus bersikap dalam menghadapi masalah ini? Dan lebih khusus lagi, bagaimana lembaga pendidikan tinggi Islam di Indonesia harus memposisikan perannya sebagai lembaga yang mampu secara intens melakukan pemberdayaan kepada masyarakat luas.

\section{B. Filsafat Monisme vs Pluralisme}

Abraham Edel dalam salah satu artikel di Journal of Philosophy pernah membahas dua dikotomi Monisme dan Pluralisme ini secara mendetail. Dalam penjelasannya, sikap monis ataupun pluralis seseorang pada dasarnya direfleksikan dari nilai-nilai ajaran filsafat yang dianutnya. Penganut filsafat monisme pada dasarnya memandang kehidupan ini secara absolut terdiri dari satu genus saja, sehingga meskipun muncul variasi dan perbedaan definisi, semuanya tetap saling bertali berkelindan dalam satu sistem genus tersebut. Absolut monisme dengan demikian memahami bahwa dunia ini berasal dari genus yang tunggal, keberbedaan yang ada bukanlah muncul dari genus yang berbeda. Hal itu bertolak belakang dengan penganut filsafat pluralisme yang memandang dunia ini secara absolut berasal dari genus yang tidak tunggal. Oleh sebab itu, keberbedaan yang ada tidak hanya karena perbedaan definisi saja tapi juga perbedaan dari genusnya. Dengan kata lain, dunia ini terdiri dari genus yang plural dan masing-masing berdiri sendiri-sendiri, sehingga berbagai variasi yang muncul pada dasarnya tidak mempunyai hubungan antara satu dengan lainnya. "Here the claim of monism 
is that the universe has interconnectedness of a logical system; of pluralism, ..., that there are absolute unrelated systems." (Edel 1934, 566).

Ramifikasi dari pandangan di atas cukup signifikan. Dalam pandangan terhadap kultur misalnya, monisme akan menuntun kita pada satu pandangan bahwa berbagai bentuk penampilan budaya itu bermuara dari satu sumber tunggal saja; sedang paham pluralis memandang bahwa berbagai tampilan kultur itu disebabkan oleh sumber yang tidak tunggal dan tidak saling berkaitan. Demikian pula dalam hal politik, monisme akan melahirkan suatu pandangan bahwa kekuasaan puncak politik itu bersumber pada kemauan person/pihak penguasa. Hal ini berbeda dengan pluralis yang cenderung mengidentifikasikan sumber kekuasaan politik tersebut berasal dari konsen masyarakat (yang terdiri dari berbagai person), bukan si agen penguasanya (yang cenderung singular saja). Konsekuensi dari pandangan ini secara filosofis adalah bahwa bagi monisme, jika segala sesuatu di dunia ini berbeda, maka tidak ada satu pun persamaan. Sedang bagi pluralis, jika segala sesuatu itu berbeda, maka pasti ada satu hal yang tetap sama. Di sini kita melihat bahwa memegangi salah satu kubu absolut monisme maupun pluralisme sejatinya membawa kelemahan mendasar, karena, walaupun berbeda, kedua pandangan sama-sama beranjak dari pikirannya yang atomistik. Keduanya tetap memungkinkan kita terjerembab ke dalam kubangan pikiran yang hitam putih. Hal itu karena, kedua pandangan sama-sama mengesampingkan kenyataan bahwa banyak hal yang tidak dapat diperhitungkan sebelumnya dalam kehidupan dunia ini.

Di sinilah Edel mengemukakan pentingnya pandangan ketiga yaitu relativisme, baik dalam memegangi paham monisme maupun pluralisme tersebut. Dalam hal kultur, sebagaimana contoh di atas, relative monism atau relative pluralism akan menghindarkan seseorang kepada pandangan yang terfokus pada satu faktor saja. Dengan begitu, berbagai sumber kultur yang ada semuanya ditempatkan dalam satu frame dimana setiap unsurnya akan dianalisis sesuai dengan konten dan situasi 
spesifiknya masing-masing. Demikian pula dalam ranah politik, pandangan kerelatifan tadi akan mendorong seseorang untuk mengingkari sumber kekuasaan yang secara spesifik berasal pada satu kubu saja (penguasa atau masyarakat). Kerelatifan ini akan menuntun kita pada pandangan yang justru lebih komprehensif dalam memaknai sumber kekuasaan politik itu, dimana agen politik berada pada tempat yang beragam. Sumber-sumber ketaatan dengan demikian berada dalam suatu agen yang bentuknya dapat bermacam-macam dan tersebar kemana-mana, tidak hanya melulu terfokus pada satu sistem saja. Hal ini tergambar dalam ungkapan klasik: There is no single power over everything, no ultimate plural power over the same thing. Singkat kata, monisme maupun pluralisme sama-sama mempunyai nilai keunggulan maupun kelemahannya masing-masing, yang keduanya bisa diambil manfaatnya sesuai dengan konteksnya secara spesifik.

Penjelasan Edel di atas sebetulnya ingin mengingatkan kita bahwa dalam menghadapi perdebatan mengenai pluralisme vs monisme itu kita jangan terjebak dalam perspektif yang absolutis. Karena hal itu hanya akan membawa kita pada kecenderungan untuk selalu membentur-benturkan kedua isme tersebut tanpa ada usaha untuk menemukan variabel rekonsiliatifnya. Dan ini tampaknya memang yang menjadi tren kita dalam menghadapi berbagai kenyataan nilai yang ada dalam kehidupan ini: menggunakan pendekatan konflik terhadap semua keberbedaan yang ada sedemikian rupa sehingga mengesampingkan segala kemungkinan rekonsiliasinya. Pendekatan semacam ini absurd karena fenomena kehidupan yang teramat kaya dan variatif ini hanya akan dibatasi dalam perspektif dua sisi koin yang tidak pernah sama. Kehidupan hanya dilihat dari dua dimensinya yang bertolak belakang ( $\mathrm{x}$ dan y) saja tanpa memperhatikan dimensi ketiga (z) nya yang bisa mempertemukan dimensi yang bertolakan tadi. Dan ini berlawanan dengan kenyataan kehidupan kita di atas bumi yang bulat ini, karena, ke mana pun arah kita melangkah akan senantiasa bisa bertemu dalam satu titik yang sama dengan orang lain yang menempuh arah yang awalnya 
berlawanan dengan kita. Namun sayangnya, bentuk keabsurdan seperti itulah yang sekarang ini tampaknya tengah menggelayuti kehidupan kita di atas tanah yang plural ini.

\section{Pluralisme Bangsa}

Keragaman nilai dan pandangan hidup yang dianut oleh masyarakat Indonesia sungguh merupakan kenyataan yang tak terbantahkan lagi (self-evidence). Penduduknya hidup mendiami ribuan pulau yang tersebar dalam rentetan sekitar garis khatulistiwa sepanjang 3.977 mil antara Samudra Hindia dan Samudra Pasifik. Kita menghitung, bangsa kita memiliki tidak kurang dari 17.508 pulau; mempunyai 742 bahasa asli daerah yang tidak pernah ditinggalkan oleh masing-masing lingkaran masyarakat adat pemakainya. Kita menjumpai berbagai bentuk adat daerah dengan kultur dan nilai lokalnya masing-masing yang walaupun tidak bisa melawan arus air bah kehidupan modern namun tetap bisa bertahan, seberapa pun terbatasnya eksistensi nyawa adat istiadat tersebut. Pluralisme bangsa ini dengan demikian bukanlah sekadar idea atau nilai abstrak yang memerlukan pembuktian lebih lanjut, karena bangsa ini memang mewujud dari kenyataan sederhana kehidupan manusia yang beragam dalam arti yang sebenarnya.

Namun demikian, kenyataan pluralitas nilai tadi harus dihadapkan dengan nilai-nilai baru dari luar yang secara epistemologis berbeda dengan nilai-nilai yang sudah sejak lama dianut oleh masyarakat asli kita. Seketika saat bangsa ini hendak didirikan, masyarakat kita dihadapkan pada polemik adopsi nilai-nilai Barat dalam sistem nation-state yang memang sudah sejak awal penjajahan senantiasa dicekokkan ke dalam sistem kemasyarakatan kita. Di sini kita paham bahwa sistem negara-bangsa yang diimpikan mewujud dalam kesadaran bersama kehidupan bermasyarakat kita tidak lain adalah sebuah entitas yang diciptakan berdasar pada suatu nilai asing yang tidak sepenuhnya dikenal dalam sistem nilai lokal masyarakat Nusantara. Karena itu, kemerdekaan bangsa ini dari penjajahan sejatinya tidak 
hanya menciptakan euphoria massal kegembiraan terbebasnya kita dari belenggu penindasan manusia atas manusia yang lain, tetapi juga awal dari kebingungan baru menghadapi kompleksitas pluralisme nilai dan tatanan hidup, tidak hanya antar sistem nilai lokal yang berlaku dalam masyarakat asli tetapi juga dalam rangka penghadapan nilai-nilai lokal tersebut dengan nilai-nilai baru yang berasal dari luar.

Dengan begitu, enigma baru yang mengiringi lahirnya bangsa baru tersebut sesungguhnya berpusar pada konflik nilai yang muncul akibat dari perbedaan filsafat nilai monisme (yang mau tidak mau harus ikut ditanamkan sejak awal oleh sistem negara-bangsa) dengan nilai-nilai pluralisme yang sudah lama menjadi perilaku jamak masyarakat pribumi. Di satu sisi, nationstate modern menghendaki nilai monisme menjadi nyawa dari tubuh sistem negara tersebut karena program-program modernisasi hanya bisa dilakukan jika sumber politik negara berada pada satu agen yang tunggal dan tidak tersebar (non-dispersed). Sementara, di sisi lain, kenyataan pluralisme sudah menjadi conditio sine qua non dari kehidupan masyarakat adat itu sendiri. Dus, di sinilah benturan antara ajaran monisme yang ingin diwujudkan dalam kehidupan berbangsa dan bernegara modern dengan pluralisme yang sudah telanjur berurat berakar dalam masyarakat. Walhasil, konflik laten antara filsafat monisme vs pluralisme sebagaimana di atas mau tidak mau harus mengejawantah dalam setiap relung sendi kehidupan nation-state tersebut.

Jadi, adakah kita mendapatkan berkah atau malahan laknat dengan berhasilnya kita mendirikan negara-bangsa Indonesia ini? Inilah sesungguhnya enigma yang harus kita hadapi sejalan dengan keberhasilan bangsa kita memproklamirkan kemerdekaan dari penjajahan sejak 75 tahunan lalu. Disini, persoalan sesungguhnya tidak terletak pada keraguan akan kemanfaatan kita menyatukan anak bangsa yang beragam ini dalam satu wadah kebangsaan Indonesia, akan tetapi pada pertanyaan bagaimana kita dapat mempertemukan dua kutub filosofis yang berbeda antara jiwa monisme yang dibawa oleh sistem nationstate tersebut dengan pluralisme yang sudah menjadi realitas 
yang tak terhindarkan lagi.

Persoalan tersebut sesungguhnya merupakan konsekuensi logis dari benturan antara dua nilai yang berbeda yang merupakan anak dari benturan antara dua peradaban yang berbeda, yaitu tradisional dan modern. Masyarakat adat kita yang sudah ratusan tahun hidup dalam satuan-satuan lokal yang terpisah satu dengan yang lain adalah bentuk entitas kehidupan yang plural secara par excellence. Secara kultur maupun politik, masyarakat tradisional tersebut menerima nilai-nilai pluralisme secara taken for granted karena mereka cenderung hidup dalam lingkaran komunal lokal dan kedaerahan yang dispersed dan mandiri hubungannya antara satu komunitas dengan yang lainnya. Persoalannya, kemudian mereka dipaksa untuk menghadapkan nilai-nilai pluralisme yang sudah telanjur immersed tersebut dengan kemauan peradaban modern yang dibawa oleh sistem negara-bangsa. Yang terjadi kemudian memang suatu proses adaptasi yang dipaksakan (forced adaptation), dimana masyarakat adat lokal harus mengubah peri kehidupan dan tingkah laku mereka disesuaikan dengan keinginan peradaban modern tersebut.

Perjalanan sejarah bangsa kita menjadi saksi dari benturan antar peradaban ini, dan sisa-sisa benturan pun masih terasakan hingga kini di berbagai ranah kehidupan berbangsa dan bernegara. Dalam hal kehidupan politik, benturan filsafat monisme dengan pluralisme tersebut masih terasakan, yang terefleksikan sekarang dengan kuat dalam polemik pemerintahan sentralis vs otonomi daerah. Beberapa undang-undang perpolitikan kita sudah sangat mengarah kepada penyebaran kekuasaan politik kepada pemerintahan lokal/daerah yang begitu kuat, namun demikian kita melihat amanat undang-undang tersebut masih belum semaksimalnya terimplementasikan dalam berbagai peraturan di bawahnya karena filsafat sentralisme yang masih sangat menjiwai perilaku kehidupan berbangsa dan bernegara kita selama ini. Dalam hal kultur pun kita melihat betapa monisme masih menjadi nyawa karena masih saja dihidup-hidupkan kebiasaan satu kultur dominan yang mengancam kehidupan kultur-kultur lokal di daerah. Terlebih dalam bidang hukum, kita 
melihat polemik monisme vs pluralisme ini masih belum mampu kita selesaikan dalam program pembangunan Hukum Nasional Indonesia. Hingga kini, bangunan filosofis Hukum Nasional kita masih didominasi oleh nilai monisme hukum karena uniformisme hukum di segala bidang kehidupan bangsa masih menjadi cita-cita utama program pembangunan hukum nasional tersebut, yang mau tidak mau melemahkan semangat pluralisme hukum yang menjadi nyawa hukum adat.

Polemik pluralisme vs monisme yang dialami oleh bangsa kita sebagaimana di atas sesungguhnya bukanlah sesuatu yang unik. Bangsa-bangsa lain, baik di belahan Eropa, Amerika hingga Asia dan Afrika, semua menghadapi polemik sejenis, bahkan banyak di antara mereka yang harus rela menumpahkan darah sesama demi tercapainya penguasaan satu nilai terhadap nilai yang lain. Benturan-benturan itu tidak lain karena sebagian besar (kalau tidak untuk mengatakan semuanya) bangsa-bangsa yang terlahir tersebut secara fanatik memegangi satu teori kekuasaan negara yang dominan dan mutlak penguasaannya terhadap segala peri kehidupan masyarakatnya. Mereka mengikuti doktrin tradisional kekuasaan negara (traditional doctrine of state sovereignty) yang mengikuti skema kekuasaan negara dari Bodin, Hobbes serta lebih spesifik lagi dalam bidang hukum dari John Austin (Austinian school of law). Bagi kalangan tradisionalis ini, kekuasaan negara tidaklah seharusnya terpisah-pisah; dan dia haruslah menjadi agen tunggal kreasi kuasa yang berada di atas agen-agen kekuasaan lain yang berada di luar negara (non-state agents of sovereignty). Dengan senjata hukum negara (state law) yang secara formal diciptakan melalui lembaga legislatif negara, pranata-pranata sosial yang berurat berakar dalam masyarakat lokal harus dicabut atau terpaksa tercerabut dari akarnya karena gelombang kekuasaan negara yang merajalela. Di negara kita, pengalaman benturan itu masih kita rasakan dengan sangat dalam hingga sekarang, khususnya dalam persoalan-persoalan hukum publik dimana encounter antara negara dan non-negara selalu saja dipaksakan untuk memberikan hasil kemenangan kepada institusi negara. 
Sejatinya, sejak paruh kedua abad dua puluh, pergeseran telah terjadi dalam hal teori kekuasaan negara ini. Teori tradisional mulai ditinggalkan dan beralih kepada teori baru yang lebih memperhatikan keragaman agen kuasa yang berada di luar institusi negara. Inilah yang kemudian disebut dengan Pluralistic state dimana penerimaan terhadap sumber-sumber kekuasaan di luar negara itu didasari pada nilai baru yang mengajarkan suatu paham bahwa kekuasaan (sovereignty) apapun bentuknya tidaklah tunggal; tidaklah kekuasaan itu tidak bisa dibagi dan negara tidaklah seharusnya absolut dalam kekuasaannya. Sebagaimana keterangan Francis W. Coker bahwa: "The pluralists maintain that sovereignty is not, in any community, indivisible, and they deny that the state either is or ought to be sovereign in any absolute or unique sense" (Coker 1921, 186). Pandangan pluralis dalam hal kekuasaan negara ini didasari pada kecenderungan politik dan sosial masyarakat modern yang semakin membatasi jangkauan kekuasaan institusi negara karena suatu keyakinan bahwa desentralisasi kekuasaan negara justru bakal berakibat baik pada peningkatan kesejahteraan ekonomi, moral dan intelektual dari warga masyarakat bangsa itu sendiri.

Perlu kita pahami bahwa kebangkitan paham pluralistic state tersebut sebagiannya merupakan akibat langsung dari kulminasi tren dalam pemikiran hukum -utamanya yang muncul di Jerman dan Inggris-yang kemudian berpengaruh secara paralel dalam pemikiran ekonomi, sebagaimana yang muncul di Perancis. Di Jerman, teorisi hukum, Otto Gierke, seawal 1868 dalam karyanya Das Genossenschaftsrecht, telah mengemukakan teorinya tentang personalitas asosiasi korporat (corporate association) dalam hubungannya dengan negara. Dalam pandangannya, teori politik dalam negara haruslah dibangun atas dasar suatu pemahaman bahwa perkumpulan atau asosiasi yang ada bukanlah sesuatu yang artifisial dan fiktif sifatnya, akan tetapi dia adalah nyata dan natural, dimana keberadaannya bersifat independen dan tidak musti tergantung kepada negara itu sendiri. Dengan kata lain, suatu perkumpulan atau asosiasi yang dibentuk oleh warga masyarakat secara hukum diakui personali- 
tasnya dan independensinya dari negara. Pandangan Gierke ini kemudian di Inggris diikuti oleh F. W. Maitland dan Neville Figgis yang lebih jauh mengembangkan teori personalitas asosiasi tersebut menjadi lebih jelas lagi, utamanya dalam hal kedudukan independennya di hadapan institusi negara. Di sinilah kemudian dapat lebih diestablishkan lagi secara keilmuan bahwa asosiasi merupakan suatu entitas yang bebas dan mandiri dari pengaruh negara walaupun ia berada dalam wilayah negara tersebut, karena itu pandangan ini menjadi dasar dari teori yang menolak negara sebagai satu-satunya entitas politik yang all-embracing dan mendominasi asosiasi-asosiasi yang lain.

Pandangan dari Gierke, Maitland dan Figgis itulah yang menjadi pilar awal dari pembentukan teori pluralistic state, walaupun sesungguhnya pendapat-pendapat mereka belum dengan jelas menggambarkan misi dasar dari teori tersebut. Teori politik yang mereka kembangkan saat itu lebih menggambarkan teori politik federalisme ketimbang politik pluralisme karena sebebas apapun asosiasi yang ada tetap harus tunduk kepada institusi negara yang melingkupinya. Inilah inti dari ajaran negara atau state sebagai communitas communitatum. Pada perkembangannya, para ilmuwan kemudian lebih melihat teori state ini dari perspektif hukum ketimbang aspek kekuasaannya. Disini, negara lebih dipandang bukan sebagai pemilik kekuasaan (sovereignty) tersebut tapi justru sebagai institusi yang harus mentaati hukum, karena hukum berada di atas negara itu sendiri. "Law is not the creation of the state; it is superior and anterior to the state." Dengan pandangan seperti ini, maka negara bukanlah institusi yang mendominasi person atau asosiasi dari person-person yang hidup dalam lingkup wilayah negara tersebut. Bahkan sebaliknya, tak ubahnya person atau asosiasi, negara juga harus tunduk pada aturan hukum.

Dimungkinkannya pemahaman seperti itu karena hukum tidak lain adalah kontrak sosial yang diciptakan untuk semata kesejahteraan bersama masyarakat. Basis dari hukum adalah solidaritas sosial atau sosial interdependensi, karena kenyataan bahwa manusia tidaklah dapat mencapai kebahagiaan dan keter- 
aturan tanpa kehidupan bersama. Lebih konkrit lagi, pandangan seperti ini membawa kepada satu teori bahwa karena negara bukanlah institusi yang berada di luar lingkup hukum maka ia juga mempunyai kewajiban yang sama untuk menjaga kehidupan sosial dan mencegah dari segala perbuatan yang dapat menghancurkan kehidupan bersama umat manusia. Di sinilah letak kesetaraan antara institusi negara dengan institusi-institusi lain yang lebih kecil. Jalan pikir seperti inilah yang dikemukakan oleh Coker ketika ia menulis:

As the characteristic attribute of the state today, the idea of public service must replace the idea of sovereignty. Whatever power the state may legitimately exert, it possesses only by virtue of the relation of such power to the provision of public services in response to social needs; the acts of those who govern create no obligation and have no legal validity save as they contribute to such an end. (Coker 1921, 189-190).

Karena negara tidak lain adalah satu dari sekian macam bentuk perkumpulan manusia (human association), maka pemerintah yang menjadi pemangku kekuasaan dalam negara tersebut tidak lain sekadar sebagai "manager of the nation's business." Dia bukanlah penguasa yang memiliki kekuasaan tanpa batas, akan tetapi sekadar sebagai pelayan dari kebutuhan sosial masyarakat untuk mencapai kemakmuran dan kebahagiaan hidup yang diidamkan bersama oleh masyarakat yang tergabung dalam negara-bangsa tersebut. Dengan kata lain, pemahaman yang pluralis tentang kesetaraan kewajiban hukum bagi institusi negara maupun non-negara telah memunculkan pemahaman tentang kewajiban negara untuk memberikan pelayanan yang sebaik-baiknya kepada masyarakat agar supaya kehidupan sosial dapat berjalan dengan baik dan pada akhirnya hukum dapat ditegakkan untuk menjaga kehidupan bersama umat manusia.

Perlu dikemukakan di sini bahwa pemikiran tentang pluralistic state tersebut pada dasarnya dipicu oleh dua kenyataan hukum: Pertama, bahwa penciptaan hukum negara (loi) pada prakteknya tidak bisa menjadi hak prerogatif dari salah satu 
organ saja dalam institusi negara; proses ini haruslah dilakukan dengan melibatkan berbagai organ. Dan kedua, bahwa setiap organ dalam institusi negara tersebut bersifat terbatas dan tidak bisa menghindarkan diri dari keterbatasan-keterbatasan tertentu. Lebih lanjut, menurut Duguit, sebagaimana dikutip oleh Coker, kenyataan-kenyataan hukum tersebut dipengaruhi secara kuat oleh tiga faktor pertimbangan: (1) faktor bentuk dasar (nature) dari hukum negara bersangkutan; (2) keterbatasan yudisial terhadap tindakan-tindakan administratif tertentu; dan (3), semakin diterimanya prinsip-prinsip responsibilitas negara (state responsibility) dalam diskursus hubungan negara dan masyarakat. Maka, dari sinilah muncul pemahaman bahwa kewajiban ketaatan kepada hukum negara itu bukan didasarkan oleh pertimbangan kekuasaan negara (state sovereignty) atau pandangan atas kewajiban warga negara menaati hukum dari negara melainkan karena satu pertimbangan mendalam bahwa hukum tersebut ditaati karena manfaat sosial yang dihasilkannya. "Statutory laws are obligatory in character not because of their sovereign origin but because of the objective ends which they serve." (Coker 1921, 192).

Atas dasar doktrin pluralistic state inilah, kita melihat sikap yang cenderung positif dan terbuka dari institusi negara -negara di Barat terhadap berbagai institusi hukum lokal yang hidup dalam masyarakat. Bahkan, kemudian, atas dasar kewajiban negara untuk memberikan pelayanan yang sebaik-baiknya kepada kehidupan sosial masyarakat (public services), maka institusi negara terdorong untuk memberikan perhatian yang lebih besar kepada berbagai tradisi dan nilai budaya yang ada tanpa harus merasa kehilangan kekuasaan politiknya. Dengan begitu, perspektif negara sebagai pelayan kepentingan sosial masyarakat telah mampu menepis sekat-sekat psikologis dalam hubungan antara agen kuasa negara dan non-negara, yang tentu saja akan sulit untuk dihilangkan bila perspektif negara sebagai pemegang kuasa tunggal tetap dipertahankan. 


\section{Problema Pluralisme}

Sebagaimana dikemukakan sebelumnya, keberagaman bangsa Indonesia adalah kebenaran yang terbukti dengan sendirinya. Namun, kita juga melihat, betapa pluralisme sering tidak membuahkan rahmat tapi justru laknat, utamanya bila bangsa ini tidak mampu memenej keberbedaan tersebut dengan baik. Sudah terbukti di berbagai belahan dunia (Muslim maupun non-Muslim), bentrokan dan pertumpahan darah mengalir tak henti karena berbagai unsur keberagaman dalam masyarakat senantiasa dibenturkan-benturkan untuk saling berkompetisi memperebutkan dominasi. Kita seolah tak mampu menghindarkan diri dari perangkap monisme walaupun kita hidup di tengah suasana pluralisme. Dus, apa yang sesungguhnya urgen dalam hal ini adalah manajemen dan pengaturan agar pluralisme tidak merusak keindahan kehidupan itu sendiri.

Sejarah bangsa kita menunjukkan, betapa keberagaman yang ada masih belum mampu kita manfaatkan dengan baik, bahkan sering menjadi pemicu perpecahan antar anak bangsa itu sendiri. Kita juga masih cenderung mengesampingkan hikmah-hikmah kehidupan yang lahir dari dalam bangsa kita sendiri. Tentu tidaklah lahir dengan begitu saja, ketika Mpu Tantular pada abad ke-14 M. dalam karyanya Sutasoma mengemukakan kata-kata bijak: "Bhinnêka tunggal ika tan hana dharma mangrwa” (yang secara literal berarti: Mereka memang berbeda, tetapi mereka berasal dari sesuatu yang sama, karena tidak ada dualitas dari satu kebenaran.). Tentu untaian kata hikmah itu muncul dari hasil pergumulannya dengan kenyataan kehidupan yang penuh warna warni keberbedaan dan keragaman, yang pada masa Tantular saat itu ditandai dengan polemik perbedaan antara Hindu -khususnya yang memuja Siwa-- dan Budha. Tentu saja Mpu Tantular belum menghadapi pertentangan antara pluralisme vs monisme seperti yang mewujud dalam benturan antara uniformisme yang dibawa nation-state Barat dengan pluralisme yang menjadi urat nadi masyarakat adat. Tetapi ia tentu sudah aware dengan fenomena benturan antara dua isme tersebut 
ketika akhirnya ia memberi simpul ikatan "kebersatuan dalam keberagaman" (unity in diversity) sebagai frase yang menggambarkan kehendak untuk berkumpul dalam satu ikatan meskipun perbedaan tetap dipertahankan eksistensinya. Mpu Tantular dengan demikian sejalan dengan berbagai pemikir modern yang sudah kita kutip di atas; bahwa betapa kita sebetulnya tidak harus membenturkan antara dua nilai karena kebersatuan itu tidak mesti menghendaki uniformisme, sebagaimana pluralisme tidak mesti menghendaki pemisahan yang rigid antara nilai-nilai yang berbeda di dalamnya.

Yang diperlukan adalah perangkat aturan untuk mengatur lalu lintas hubungan interpersonal dalam lingkup masyarakat yang majemuk. Namun sayang, pengalaman menunjukkan bahwa bangsa kita cenderung mengabaikan kepentingan akan adanya aturan main tersebut. Bahkan yang terjadi, dalam beberapa segi negara terlalu dominan peranannya dalam mendesakkan nilai-nilai monisme dalam kehidupan berbangsa dan bernegara ini. Hal itu tampak, utamanya selama pemerintahan Orde Baru yang begitu persistent dalam mengimplementasikan prinsip-prinsip kebersatuan dan keseragaman demi mewujudkan efektifitas lembaga-lembaga negara. Karena terlalu dominannya posisi lembaga eksekutif dalam mengendalikan gerak mesin pemerintahan, maka negara telah memerankan dirinya sebagai agen tunggal pengejawantahan prinsip-prinsip nation-state modern secara absolut. Hal itu ditandai dengan dihidupkannya sifat-sifat negara-bangsa yang begitu monistik dengan menghapus berbagai tatanan lokal yang sudah mapan dalam kehidupan sehari-hari masyarakat. Walhasil, negara betul-betul menjadi penguasa bagi rakyatnya, dan tertepislah prinsip-prinsip pelayanan sosial yang semestinya menjadi nyawa dari hubungan antara institusi negara dengan masyarakat.

Yang lebih menarik lagi dari fenomena dominasi institusi state tersebut adalah dihapuskannya secara teoritik sistem hukum interpersonal (intergentiel recht) di Indonesia seiring dengan semakin menguatnya konsep Hukum Nasional. Sebagai sebuah sistem, hukum interpersonal sebenarnya sudah mulai 
dibangun dasar-dasarnya di tanah Nusantara ini oleh pemerintah penjajahan Belanda karena kepentingannya untuk mengatur hubungan antar person dari warga negara yang tunduk kepada tradisi hukum yang berbeda. Namun rupanya, paham nasionalisme di satu sisi dan uniformisme hukum di sisi lain telah mampu memandulkan sistem interpersonal law tersebut dalam sistem hukum nasional kita. Inilah bukti nyata dari dominasi monisme absolut sebagaimana di atas: menghilangnya aturan-aturan yang mengatur hubungan interpersonal tersebut jelas menunjukkan bahwa, minimal dalam tataran sistem hukumnya, bangsa ini lebih cenderung kepada prinsip-prinsip monisme ketimbang pluralisme, terlepas dari kenyataan kemajemukan dan keberagaman kehidupan masyarakatnya.

Dalam tataran yang lebih luas, mandulnya prinsip-prinsip interpersonal law di atas memberikan konsekuensi logis akan kosongnya prinsip-prinsip hukum (legal maxims) yang mengatur kehidupan pluralisme masyarakat. Inilah yang tengah berlangsung dalam masyarakat kita: pluralisme dibiarkan saja berjalan dalam masyarakat tanpa diikuti oleh tata aturan yang berfungsi memenej pluralitas tersebut. Dengan kata lain, kita hidup di atas landasan teori yang kosong melompong, atau bahkan tanpa teori sama sekali. Sebagai akibatnya, berbagai konflik dan ketegangan yang muncul dalam masyarakat sebagai akibat dari pluralisme pada prinsipnya tidak bisa dipecahkan dengan menggunakan landasan teori hukum yang sehat. Hal itu karena sifat monistik hukum nasional telah dengan sendirinya menafikan prinsip-prinsip hukum pluralis. Begitulah, pluralisme telah melahirkan enigma yang tak berkesudahan!

Ramifikasi dari pendekatan monisme di atas sangatlah luas, karena hal itu sangat menentukan sikap dan tingkah laku negara dalam menghadapi kasus-kasus pluralisme yang melibatkan berbagai ranah kehidupan masyarakat. Berbagai kasus dan peristiwa konflik muncul utamanya semenjak jatuhnya pemerintahan Soeharto, yang semuanya itu berakar dari konflik antara anggota masyarakat yang mempunyai nilai budaya dan keyakinan yang berbeda-beda. Menariknya, berbagai konflik dan 
ketegangan tersebut senantiasa diikuti oleh konflik multidimensional yang menambah rumit jalan pemecahannya, terutama bila masyarakat yang berkonflik semata-mata mengharapkan uluran tangan institusi negara untuk resolusinya. Di sinilah pentingnya memahamkan masyarakat untuk lebih mendewasakan diri dalam menghadapi kenyataan pluralisme dan mendidik kemandirian mereka dalam menghadapi dan memenej konflik yang muncul di antara mereka. Dan di sinilah poin penting yang ingin penulis sampaikan: bahwa lembaga pendidikan tinggi seharusnya dapat memainkan perannya dalam proses pendidikan masyarakat sehingga mereka lebih siap dalam menghadapi realitas pluralisme bangsa ini.

\section{E. Peran Perguruan Tinggi Islam di Indonesia}

Lalu, bagaimana sesungguhnya peran lembaga pendidikan kita di Tanah Air dalam menghadapi enigma pluralisme bangsa yang sedang kita hadapi ini saat ini? Adakah peran yang sudah dimainkan? Bagaimana pula dengan perguruan tinggi Islam yang sesungguhnya mempunyai posisi yang sangat strategis karena kenyataan umat Islam sebagai penduduk mayoritas di negeri ini?

Tidak bisa disangkal lagi, bahwa kemunculan Perguruan Tinggi Keislaman Indonesia (PTKI) juga sebagiannya karena hasil kompromi politik. Sebagaimana kita ketahui bersama, persaingan dominasi antara kelompok nasionalis sekular dan agamis yang muncul seawal kemerdekaan bangsa ini pada akhirnya telah merambah ke berbagai bidang kehidupan kemasyarakatan kita, termasuk di dalamnya dalam kerangka berpikir kita tentang wujud institusi pendidikan Islam itu sendiri. Karena itu, sedari semula kita bisa memahami bahwa lembaga-lembaga pendidikan tinggi Islam yang ada tidak lain adalah ujud nyata dari hasil pergulatan antar berbagai elemen anak bangsa ini dalam mendefinisikan jalan keluar dari persaingan ideologi bangsa.

Satu hal pasti, bahwa Perguruan Tinggi Keislaman Negeri terlahir dalam kerangka kesepakatan umat Islam di Tanah Air untuk menerima ideologi nation-state sebagai sarana untuk 
mewujudkan persatuan bangsa. Di sini, keberadaan STAIN, IAIN ataupun UIN tidak bisa dilepaskan dari kerangka keinginan bangsa ini untuk mengapresiasi berbagai elemen perbedaan nilai dan paham keyakinan yang hidup dalam masyarakat dan mempersatukannya dalam wadah kesatuan bangsa yang plural. Dengan mengadopsi term state legal pluralism dari John Griffith, state pluralism dengan demikian menjadi ideologi besar yang bisa memungkinkan munculnya lembaga pendidikan agama yang resmi dimiliki oleh negara, walaupun sejak awal bangsa ini bukanlah mendasarkan dirinya pada satu nilai ajaran agama tertentu. Tak ayal lagi, "Kebersatuan dalam keberagaman" sebagaimana yang tercermin dalam frasa Bhinneka Tunggal Ika, sesungguhnya menjadi landasan epistemologis dari pilihan ideologi state pluralism tersebut, karena perbedaan-perbedaan yang ada tidak dimaknai secara absolut sebagai bentuk pluralisme yang nir-dialogue. Dengan kata lain, keberadaan perguruan tinggi Islam (atau bahkan perguruan agama lainnya) dalam wadah institusi resmi negara sejatinya merupakan jalan tengah yang paling mungkin dilakukan untuk menggapai kebersatuan di negeri yang sangat plural ini.

Mengikuti alur pikir di atas, tidaklah berlebihan jika dikatakan bahwa masyarakat sesungguhnya menaruh harapan yang sedemikian besar pada Perguruan Tinggi Islam. Harapan utamanya digantungkan kepada institusi pendidikan ini untuk mampu turut serta memberikan resolusi dari berbagai ketegangan dan konflik yang ada dalam masyarakat akibat dari benturan berbagai macam paham dan nilai yang hidup di dalamnya. Harapan ini logis karena pendirian lembaga pendidikan tinggi agama oleh institusi negara sebetulnya lebih dilandasi oleh semangat pluralisme ketimbang monisme. Dengan kata lain, pendirian perguruan tinggi bernuansa keagamaan ini dilandasi semata oleh kepentingan negara untuk mewujudkan kesejahteraan dan keadilan sosial yang dikehendaki oleh seluruh masyarakat. Dan ini hanya bisa diwujudkan jika sejak awal negara mempunyai komitmen untuk menerapkan ideologi pluralistic state dalam logika kepemerintahannya, dimana logika 
negara sebagai pelayan kepentingan sosial (public service) lebih dikedepankan ketimbang perannya sebagai agen kuasa tunggal (state sovereign).

Satu hal yang secara strategis dapat dimainkan oleh Perguruan Tinggi Islam ini adalah berhubungan dengan perannya untuk terus melakukan pemberdayaan masyarakat agar bisa memahami hakikat kehidupan yang plural tersebut. PTKI kita semestinya lebih proaktif dalam melakukan pendidikan pluralisme di akar rumput, karena sejak awal kajian keislaman (Islamic studies) yang dilakukan dalam lembaga pendidikan ini adalah kajian yang pluralis sifatnya. Baik dari perspektif kognitif maupun afektif, kajian Islam adalah kajian tentang fenomena pluralisme itu sendiri secara par excellence. Kajian Islam bukanlah kajian yang monolitik sifatnya karena pada dirinya sendiri ia mengejawantah dari berbagai bentuk variasi pemikiran dan penganalisaan. Karena itu, perspektif yang monistik dalam mengkaji Islam justru akan merusak sistem ilmu itu sendiri dari dalam.

Revitalisasi peran PTKI itu utamanya harus dilakukan dengan mendekatkan kajian-kajian keislaman dengan kenyataan sosial kehidupan masyarakat dimana kita ada di dalamnya. Kajian Islam bukanlah kajian tentang alam akherat semata, ia adalah sistem kajian dari, tentang dan untuk kehidupan dunia ini juga. Oleh karena itu, ia tidak boleh dipisahkan dari fenomena sejarah kehidupan umat manusia itu sendiri. Atau, dengan kata lain, subjek kajian keislaman yang kita lakukan tidak boleh dipisahkan dari kajian-kajian lain yang non-agama. Dan hal itu bisa dilakukan utamanya melalui pembenahan kurikulum dan silabi dari berbagai subjek kajian keislaman di PTKI sehingga kajian tersebut lebih living dan enlightening karena subjek yang dibahas di dalamnya bukanlah sesuatu yang beyond the history of human beings. Hal itu bisa dicapai jika para konseptor di balik proses penciptaan kurikulum itu tidak terpasung oleh kejumudan dan kekakuan pandangan, tetapi lebih menekankan pada kedalaman dan keluasan perspektif kajian. Dus, penekanan diberikan tidak pada formal curriculum tetapi lebih pada hidden curriculum yang 
memungkinkan semua peserta proses pembelajaran mengeksplor berbagai pandangan yang nyata hidup dalam masyarakat. Karena itu, tidaklah bisa dipahami bahwa proses pembelajaran yang sehat hanya bisa dilakukan di dalam ruangan kelas saja, bahkan semestinya harus diperluas cakupan ruangannya agar bisa mengkover kekayaan kajian Islam itu sendiri. Di sinilah makna pluralisme itu akan mampu untuk direfleksikan, karena kajian Islam tidak lagi sekadar bentuk reproduksi nilai-nilai lama dalam bingkai baru tetapi merupakan kajian yang mampu mendorong peserta didik memiliki wawasan yang luas tentang keanekaragaman nilai dan denominasi dalam masyarakat.

Dari segi konten kajiannya, studi Islam yang kita lakukan di PTKI sudah sewajarnya tidak lagi beraroma yang sama dengan kajian keislaman dalam bentuknya yang lama. Sudah tepat apa yang kita lakukan selama ini untuk tidak memisahkan secara rigid antara tradisi keilmuan Islam dan non-Islam karena pengkotakan yang kaku hanya akan berakibat pada pemandulan kemampuan untuk memahami keberagaman kajian ilmu itu sendiri. Perspektif studi semacam ini tentu akan berdampak positif untuk membangkitkan kemampuan berpikir dan bertingkah laku pluralis bagi seluruh peserta didik, sehingga bisa tercipta atmosfir yang nyaman, terbuka dan saling menghargai dari berbagai ranah bidang studi yang kita kembangkan. Pengayaan perspektif dan pendekatan karena itu sudah merupakan suatu kewajiban bagi kita semua, civitas academica di perguruan tinggi ini, jika memang peran yang diharapkan dari masyarakat ingin kita penuhi.

Di Fakultas Syari'ah, sebagai contoh, kajian hukum yang menekankan perbandingan terhadap berbagai bentuk tradisi hukum di dunia mesti bisa mulai ditradisikan. Hal itu diperlukan untuk menjawab tantangan zaman terhadap institusi hukum Islam itu sendiri yang dipostulatkan sebagai tradisi hukum agama yang humanistik, sosiologis, dan kontekstual. Hukum Islam juga tidak semestinya lagi dikaji dengan perspektif lama yang memisahkan secara rigid antara tradisi hukum sakral dan hukum sekular karena hakikatnya tradisi hukum apapun di 
dunia ini berasal pada akar filosofis yang sama yaitu tercapainya keadilan dan keteraturan kehidupan umat manusia. Logika ini pun juga berlaku bagi fakultas-fakultas lain, karena, kenyataan kecenderungan kita yang secara umum masih membingkai kajian-kajian keislaman pada kotak keilmuan sakral yang terpisah dengan yang sekular.

Pada dataran yang sama, improvisasi kurikulum dalam penyesuaiannya dengan situasi kekinian tidaklah mungkin tercapai tanpa juga me-reorientasi sistem kelembagaannya. Mengadopsi tren kekinian dalam penyelenggaraan negara yang secara teoritik sudah dialihkan kepada pengamalan prinsip-prinsip pluralistic state dimana perilaku hubungan negara dengan masyarakat tidak lagi diorientasikan kepada perspektif kekuasaan (sovereignty) melainkan pelayanan sosial (public service), maka patutlah mulai dialihkan juga paradigma lembaga pendidikan kita dari orientasi agen kuasa menuju kepada agen penyedia layanan publik. Ini berarti bahwa para eksekutif PTKI haruslah mampu menjadi "manager of educational business" yang baik yang memahami dua dimensi pokok perguruan tinggi yaitu: dimensi lembaga akademik dan dimensi lembaga bisnis, dimana keduanya tidak mungkin bisa dipisah-pisahkan. Sebagai lembaga akademik, Perguruan Tinggi Islam harus mampu memberikan pelayanan yang sebaik-baiknya dalam pelaksanaan Tri Dharma Perguruan Tinggi dan memberikan penghargaan yang setinggi-tingginya atas prestasi akademik yang dicapai oleh peserta proses pembelajaran di dalamnya. Dan sebagai lembaga bisnis, maka mesin utama gerak manajemen perguruan tinggi ini harus diarahkan kepada perbaikan pelayanan kepada seluruh unsur civitas academica yang ada dan bukannya pencapaian kekuasaan politik segelintir individu dari masyarakat kampus tersebut.

\section{F. Penutup}

Jika benar bahwa pluralitas masyarakat Indonesia diterima sebagai suatu keniscayaan, maka tidak ada jalan lain kecuali penerimaan secara deliberate dan genuine segala bentuk kera- 
gaman yang ada dalam nadi kehidupan masyarakat tersebut. Dan dengan begitu berarti monism tidak lagi dapat digunakan sebagai nilai dasar yang melandasi pendekatan kita terhadap segala persoalan kebangsaan. Pengakuan terhadap keberagaman (diversity) lahir dari sikap dan kerangka pikir kita terhadap kenyataan. Benturan antara monism versus pluralism karenanya tidak perlu lagi terjadi jika memang kita lebih memilih nilai-nilai persamaan ketimbang perbedaannya.

Kita meyakini bahwa hanya dengan orientasi baru Perguruan Tinggi Islam sebagai pluralistic university lah maka PTKI akan mampu merevitalisasi perannya dalam institusi negara modern Indonesia, dimana hubungan antar unsur civitas academica di dalamnya tidak lagi merefleksikan bentuk relasi atas-bawah antara berbagai unsur agen kuasa, melainkan lebih sebagai hubungan sejajar dari berbagai bentuk asosiasi yang beragam yang membentuk institusi pendidikan tinggi itu sendiri. Dan hanya dengan perspektif pluralistis inilah, kita bisa yakin bahwa kajian-kajian yang dilakukan di dalam Perguruan Tinggi tersebut akan mampu merefleksikan Islam sebagai rahmat bagi seluruh umat manusia.

\section{BIBLIOGRAFI}

Beckley, Gloria T., and Paul Burstein. 1991. "Religious Pluralism, Equal Opportunity and the State." The Western Political Quarterly 44 (1): 185-208.

Coker, Francis W. 1921. "The Technique of the Pluralistic State." The American Political Science Review 15 (2): 186-213.

Edel, Abraham. 1934. "Monism and Pluralism." The Journal of Philosophy 31 (1): 561-571.

Griffith, John. 1985. "Four Laws of Interaction in Circumstances of Legal Pluralism: First Step Towards an Explanatory Theory." In People's Law and State Law: The Bellagio Papers, edited by Gordon R. Woodman dan A. Allott. Dordrecht: Foris Publications.

——_. 1986. "What is Legal Pluralism." Journal of Legal Pluralism 
Enigma Pluralisme Bangsa: Memposisikan Peran Perguruan Tinggi Islam and Unofficial Law 24: 1-55.

Lukito, Ratno. 2008. “The Enigma of Legal Pluralism in Indonesian Islam: The Case of Interfaith Marriage." Journal of Islamic Law and Culture 10 (2): 176-187.

-_- 2008b. Hukum Sakral dan Hukum Sekuler: Studi tentang Konflik dan Resolusi dalam Sistem Hukum Indonesia. Jakarta: Alvabet.

- - - 2013. Legal Pluralism in Indonesia: Bridging the Unbridgeable. London and New York: Routledge.

Parekh, Bhikhu. 1996. "Minority Practices and Principles of Toleration." International Migration Review 30 (1): 251-284. 